\title{
Utilization of used contact masses from the oxidation state of sulfur(IV) oxide to sulfur(VI) oxide
}

\author{
Mieczysław Trypuć, Krzysztof Mazurek, Urszula Kiełkowska, Sebastian Drużyński \\ Nicolaus Copernicus University, Faculty of Chemistry, ul. Gagarin 7, 87-100 Toruń, Poland, \\ e-mail: mazur@chem.uni.torun.pl
}

\begin{abstract}
The research was conducted to determine the influence of the urea concentration in the leaching solutions on the efficiency of recovery of vanadium and iron compounds from the used vanadium catalyst from the node of oxidation of sulfur dioxide to sulfur trioxide.
\end{abstract}

Keywords: sulfuric acid, sulfur oxide, urea solutions, used vanadium catalysts, leaching process.

Presented at VII Conference Wasteless Technologies and Waste Management in Chemical Industry and Agriculture, Międzyzdroje, 12 - 15 June, 2007.

\section{INTRODUCTION}

Vanadium catalysts working under the industrial conditions are deactivated due to the changes occurring in their structure and texture ${ }^{1-5}$. Withdrawn from the process, they pile up on the factory waste dumps of the concrete silos. These catalysts, subjected to the atmospheric conditions, generate the acidic reflux, harmful for the surrounding ecosystems due to the high levels of toxic substances.

The used catalysts constitute the chemically and granulometrically heterogeneous material. The composition of these catalysts strongly depends on the conditions of their usage, the source of sulfur dioxide, as well as the conditions of their storage after withdrawal from the process. Table 1 presents the composition of the used vanadium catalysts from different sources ${ }^{1-5}$.

The amount of that waste, which could be estimated as close to 4 thousand ton in Poland, and their composition indicate the necessity of the research on developing the method of their complex utilization.

Up to date, there has been no such method, which would enable the total utilization of these catalysts. Therefore, the authors initiated the development of a method, that would be both environmentally friendly and economically efficient.

The research on the use of urea solutions in such a method was initiated based on the numerous papers reporting that urea significantly affects the solubility of inorganic compounds in water. In most cases it reveals the salt in effect. Urea forms the double salts with many compounds, which reveal significantly larger solubility in water, than pure salts ${ }^{6,7}$.

Previous research of the authors on the mutual solubility in the ternary systems urea - vanadium $(\mathrm{V})$ compounds - water revealed that urea significantly affects the solubility of vanadium $(\mathrm{V})$ compounds in water. In particular, such effect was detected in the $\mathrm{V}_{2} \mathrm{O}_{5}+\mathrm{CO}\left(\mathrm{NH}_{2}\right)_{2}+$ $\mathrm{H}_{2} \mathrm{O}$ system $^{8}$. It was shown that the solubility of vanadium $(\mathrm{V})$ oxide significantly increases in the presence of urea in the solution.

The research concerned the effect of the urea concentration in the leaching solution on the ratio of the recovery of vanadium and iron compounds from the used contact masses.

\section{EXPERIMENTAL PART}

\section{Reagents}

The used vanadium catalyst was sampled from the waste deposit of POLCHEM, Toruń, Poland, the factory producing the sulfuric acid in the contact process; $\mathrm{CO}\left(\mathrm{NH}_{2}\right)_{2}$ (purity of 98\%) - PPH „Standard”, Poland.

Before research, the catalyst was milled in the vibrational mill, and divided into the appropriate granulometric fractions with the FRITSH set of sieves.

\section{Experimental methods}

The effect of the urea concentration in the leaching solution on the ratio of the recovery of vanadium and iron compounds from the used vanadium catalyst was investigated with the use of catalyst grains of $0.250-0.180 \mathrm{~mm}$ diameter at $293 \mathrm{~K}$.

Samples of the used vanadium catalyst $(5.000 \mathrm{~g})$ were put into the Erlenmeyer flasks with the magnetic stirrer. Then $50 \mathrm{~cm}^{3}$ of the urea solution of the required solution $(5,10,20,30,40$ or $45 \%)$ was pipetted into the flask; the flask was closed with the rubber stopper and thermostated, while stirred. The period of thermostating varied between 30 and 120 minutes.

The temperature was kept constant with the BIOBLOCK-SCIENTIFIC thermorelay. Additionally, the temperature was monitored with the mercury thermometer of $\pm 0.05 \mathrm{~K}$ precision.

After a selected time period, the stirring was stopped. The solution was separated from the insoluble remains of the catalyst with a sintered glass crucible by a vacuum filtration. That allowed the filtering without changing the solution temperature.

The clear solution was transferred into the flask, diluted with the distilled water and analyzed to determine the concentration of vanadium and iron compounds.

\section{Analytical methods}

Concentration of vanadium(V) in the solutions was determined spectrophotometrically by the peroxide method $^{9}$. This method might be applied for the vanadium concentration range between $8 \cdot 10^{-3}-2.16 \mathrm{~mol} \cdot \mathrm{dm}^{-3}$. The concentration of vanadium, corresponding to the measured absorbance, was calculated from the calibration curve. 
Table 1. Chemical composition of the spent vanadium catalyst

\begin{tabular}{|l|c|c|c|c|}
\hline \multirow{2}{*}{ Component } & \multicolumn{4}{|c|}{ Content [\%] } \\
\cline { 2 - 5 } & $\begin{array}{c}\text { M. Stancheva } \\
\text { Medical University Varna, } \\
\text { Bułgaria }\end{array}$ & $\begin{array}{c}\text { M. Ksibi } \\
\text { ENIG, Tunezja }\end{array}$ & $\begin{array}{c}\text { P. Grzesiak } \\
\text { Institute of Plant } \\
\text { Protection, Poznań }\end{array}$ & $\begin{array}{c}\text { S. Anioł } \\
\text { The Silesian University of } \\
\text { Technology, Gliwice }\end{array}$ \\
\hline $\mathrm{V}_{2} \mathrm{O}_{5}$ & 4.67 & 6.18 & 4.40 & 4.80 \\
\hline $\mathrm{SiO}_{2}$ & 59.11 & 48.70 & 38.90 & 49.50 \\
\hline $\mathrm{K}_{2} \mathrm{O}$ & 4.96 & 10.03 & 7.40 & 5.80 \\
\hline $\mathrm{Fe}_{2} \mathrm{O}_{3}$ & 3.36 & 1.43 & 1.50 & 2.10 \\
\hline $\mathrm{Na}_{2} \mathrm{O}$ & 3.66 & 2.32 & - & 0.10 \\
\hline $\mathrm{Al}_{2} \mathrm{O}_{3}$ & 0.82 & 2.18 & - & \\
\hline
\end{tabular}

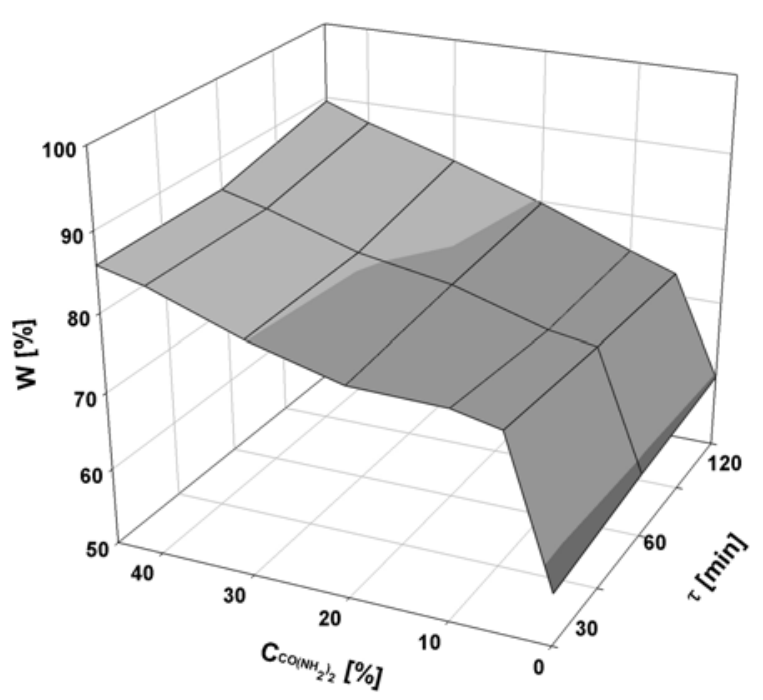

Figure 1. The influence of urea concentration in the leaching solution on the ratio of the recovery of vanadium compounds

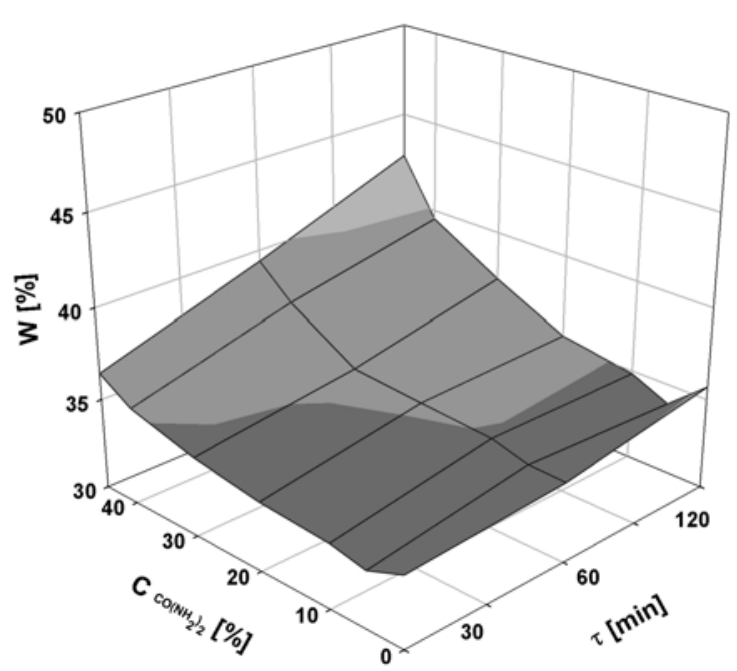

Figure 2. The influence of urea concentration in the leaching solution on the ratio of the recovery of iron compounds

Each analysis was performed for three samples, and the error of the vanadium determination had not exceeded $2 \%$.

The total concentration of iron in the solutions was determined spectrophotometrically with the use of sulfosalicylic acid. That method is based on a reaction of sulfosalicylic acid with iron(III) salts in the basic solution and formation of a yellow iron-containing complex. The analysis is performed at $\lambda=430 \mathrm{~nm}$. The determination was performed for three samples, the error had not exceeded $2 \%$.

Analyses were performed with the double-beam Hitachi $\mathrm{U}-2000 \mathrm{UV} / \mathrm{Vis}$ spectrophotometer, which allows the analyses at the wavelength range $190-1100 \mathrm{~nm}$ and -1 to 3 ABS. The $10 \mathrm{~mm}$ quartz absorption cells were used.

\section{RESULTS AND DISCUSSION}

The results of the analyses of the solutions, revealing the effect of urea concentration in the leaching solution on the recovery ratio of vanadium and iron compounds are presented on Figures 1 and 2.

The recovery ratio of vanadium and iron compounds were calculated to the excess of $\mathrm{V}_{2} \mathrm{O}_{5}-5 \%$ and $\mathrm{Fe}_{2} \mathrm{O}_{3}-$ $1.65 \%$ in the spent vanadium catalyst.

The experimental points on both plots indicate that the increase of the urea concentration results in the higher recovery ratio for both vanadium and iron compounds.

For the leaching time of 120 minutes, the lowest recovery ratio of vanadium compounds $(73 \%)$ was achieved for the urea concentration of $5 \%$ (by weight).

The highest ratio of $89 \%$ for that period of time was observed for the urea concentration of $45 \%$.

Similar relations were observed for other investigated periods of leaching the samples of the used catalyst.

For the leaching process of iron compounds, similar dependencies were observed. For an investigated leaching time, the lowest efficiency was observed for the urea solutions of $5 \%$ concentration, while the highest was detected for $45 \%$ concentration of urea.

\section{SUMMARY}

The presented research indicated that urea concentration in the leaching solution significantly affects the efficiency of the recovery of vanadium and iron compounds from the used vanadium catalyst. The efficiency increases with the increasing urea concentration.

\section{LITERATURE CITED}

(1) Grzesiak P., Schroeder G.: Kwas siarkowy(VI), technologia, ekologia, analityka, ekonomia, Wydawnictwo UAM, Poznań, 1999.

(2) Lozano L. J., Juan D.: Technical note leaching of vanadium from spent sulphuric acid catalysts, Minerals Engineering, 2001, 5, 543.

(3) Khorfan S., Wahoud A., Reda Y.: Recovery of vanadium pentoxide from spent catalyst used in the manufacture of sulphuric acid, Periodica Polytechnica Ser. Chem. Eng., 2001, 2, 131. 
(4) Ksibi M., Elaloui E., Houas A., Moussa N.: Diagnosis of deactivation sources for vanadium catalysts used in $\mathrm{SO}_{2}$ oxidation reaction and optimization of vanadium extraction from deactivated catalysts, Applied Surface Science, 2003, 220, 105.

(5) Anioł S., Korolewicz T., Kubala J.: Odzyskiwanie $\mathrm{V}_{2} \mathrm{O}_{5}$ z zużytego katalizatora wanadowego, Materiały II Kongresu Technologii Chemicznej, 1997, 510.

(6) Sułajmankułow K.: Sojedienienia karbamida s nieorganitscheskimi solami, ILIM Frunze, Russia, 1971.

(7) Poczopko S.: Sole podwójne w nasyconych roztworach soli nieorganicznych. Izotermy rozpuszczalności o dwóch punktach załamania, Rocz. Chem., 1962, 36, 111.

(8) Mazurek K.: Wyznaczenie izoterm rozpuszczalności układów trójskładnikowych mocznik - związki wanadu(V) woda, Praca doktorska, UMK, Toruń, 2004.

(9) Williams W. J.: Oznaczanie anionów, PWN, Warszawa, 1985. 